\title{
Effect of Inorganic Mercury on Hematological and Antioxidant Parameters on Olive Flounder Paralichthys olivaceus
}

\author{
Jun-Hwan Kim ${ }^{1}$, Jung-Sick Lee ${ }^{2}$ and Ju-Chan Kang ${ }^{1 *}$ \\ ${ }^{1}$ Department of Aquatic Life Medicine, Pukyong National University, Busan 608-737, Korea \\ ${ }^{2}$ Department of Aqualife Medicine, Chonnam National University, Yeosu 550-749, Korea
}

\begin{abstract}
The effects of inorganic mercury on hematological parameters and hepatic oxidative stress enzyme activity were studied in olive flounder Paralichthys olivaceus. Fish were injected twice intraperitoneally with mercuric chloride (2, 4, or $8 \mathrm{mg} \mathrm{Hg} / \mathrm{kg} \mathrm{BW})$. The major hematological findings were significant decreases in the red blood cell count, hematocrit value, and hemoglobin level in olive flounder exposed to $8 \mathrm{mg} \mathrm{Hg} / \mathrm{kg} \mathrm{BW}$. Remarkably low levels of calcium and chloride, and reduced osmolality, were also observed at $8 \mathrm{mg} \mathrm{Hg} / \mathrm{kg} \mathrm{BW}$. In hepatic tissue, significant increases in glutathione peroxidase and catalase activity were observed above $4 \mathrm{mg} \mathrm{Hg} / \mathrm{kg}$ BW Inorganic mercury also increased glutathione S-transferase and glutathione reductase activity at $8 \mathrm{mg} \mathrm{Hg} /$ $\mathrm{kg} \mathrm{BW}$ in hepatic tissue. The present findings suggest that exposure to a low concentration ( $\geq 4 \mathrm{mg} \mathrm{Hg} / \mathrm{kg} \mathrm{BW}$ ) of inorganic mercury can cause significant changes in hematological and antioxidant parameters.
\end{abstract}

Key words: Paralichthys olivaceus, Inorganic mercury, Hematological parameter, Antioxidant enzyme

\section{Introduction}

Toxic heavy metals are increasingly being released into the environment as a result of industrialization. Mercury is a nonessential element that can have severe, toxic effects on aquatic animals when present in excessive amounts (Nriagu and Pacyna, 1988; Fitzgerald and Clarkson, 1991). Most of the mercury in water, sediments, or the biota is in the form of inorganic mercury salts or organic forms. Mercury has always been present at varying levels in environmental media and the biota, and all mercury is, in a sense, naturally occurring; that is, mercury is not a substance of human origin. Anthropogenic activities are thought to redistribute mercury from its original matrix through the atmosphere to other environmental media. Numerous studies have shown that the amount of mercury being deposited from the atmosphere has increased since the onset of the industrial age (Johansson et al., 1991; Nater and Grigal, 1992; Swain et al., 1992). Some mercury deposits arise from natural sources while others are derived from anthropogenic activities.

The absorption, distribution, metabolism, and excretion of mercury depend on its form and oxidation state (Goyer, 1991). Organic mercurials are more readily absorbed than inorganic forms. An oxidation-reduction cycle is involved in the metabolism of mercury and its compounds in animals, including humans. Mercury poisoning causes necrosis in epithelial cells, epithelial hyperplasia, and $\mathrm{Na}^{+}-\mathrm{K}^{+}$ATPase inhibition in fishes (Bouquegneau, 1977; Lock et al., 1981). During early embryonic development in zebrafish, elevated mercury levels cause reduced survival time and increased hatching time (Dave and Xiu, 1991). The tissue distribution of inorganic mercury in fishes varies with the route of administration (water, oral, and intraperitoneal); however, the liver and kidneys tend to accumulate the highest quantity of this metal overall (Weisbart,
Open Access http://dx.doi.org/10.5657/FAS.2012.0215

This is an Open Access article distributed under the terms of the Creative Commons Attribution Non-Commercial License (http://creativecommons. org/licenses/by-nc/3.0/) which permits unrestricted non-commercial use, distribution, and reproduction in any medium, provided the original work is properly cited. pISSN: 2234-1749 eISSN: 2234-1757
Received 16 April 2012; Revised 18 July 2012;

Accepted 9 August 2012

*Corresponding Author

E-mail: jckang@pknu.ac.kr 
1973). Nevertheless, data on oxidative stress due to mercury exposure are lacking in fish.

Therefore, the objective of this study was to evaluate the effects of inorganic mercury delivered via an intraperitoneal injection on hematological parameters and hepatic antioxidant enzyme activity in olive flounder Paralichthys olivaceus.

\section{Materials and Methods}

\section{Experimental fish}

Olive flounders Paralichthys olivaceus were obtained from a local fish farm on Jeju Island, Korea. The fish were acclimatized for 3 weeks under laboratory conditions and their health status was evaluated prior to mercury exposure (Table 1). During the acclimation period, the fish were fed a commercial diet twice daily and maintained on a 12-h:12-h light/dark cycle at all times. After acclimatization, several fish (body length, 19.3 \pm 1.2 ; body weight [BW], $53 \pm 2.9 \mathrm{~g}$ ) were selected for further study.

\section{Exposure conditions}

Mercury exposure took place in 0.5-ton fiberglass-reinforced plastic tanks containing 25 fish per treatment group. Each tank received a flow of $7 \mathrm{~L} \mathrm{~min}^{-1}$ with continuous aeration. Mercury(II) chloride (Sigma, St. Louis, MO, USA) was dissolved in phosphate-buffered saline (PBS) immediately before intraperitoneal injection. The fish were injected with 2, 4 , or $8 \mathrm{mg} \mathrm{Hg} / \mathrm{kg} \mathrm{BW}$ as mercury chloride. The first injection was given 3 weeks after acclimatization; the second was given 1 week after the first treatment. The control group was subjected to the same regimen; however, they were injected with

Table 1. Chemical components of seawater used in the acclimation period of olive flounder Paralichthys olivaceus

\begin{tabular}{lr}
\hline \multicolumn{1}{c}{ Parameter } & \multicolumn{1}{c}{ Value } \\
\hline Temperature $\left({ }^{\circ} \mathrm{C}\right)$ & $18.21 \pm 0.30$ \\
$\mathrm{pH}$ & $8.10 \pm 0.23$ \\
Salinity $(\% \mathrm{o})$ & $31.82 \pm 0.52$ \\
Ammonia $(\mu \mathrm{g}$-at $/ \mathrm{L})$ & $13.65 \pm 1.34$ \\
Nitrite $(\mu \mathrm{g}-\mathrm{at} / \mathrm{L})$ & $2.28 \pm 0.26$ \\
Nitrate $(\mu \mathrm{g}$-at $/ \mathrm{L})$ & $9.82 \pm 1.12$ \\
Phosphate $(\mu \mathrm{g}-\mathrm{at} / \mathrm{L})$ & $6.42 \pm 0.78$ \\
$\mathrm{SS}(\mathrm{mg} / \mathrm{L})$ & $4.84 \pm 0.18$ \\
$\mathrm{DO}(\mathrm{mg} / \mathrm{L})$ & $6.95 \pm 0.43$ \\
$\mathrm{COD}(\mathrm{mg} / \mathrm{L})$ & $1.08 \pm 0.04$ \\
\hline
\end{tabular}

an equal volume of PBS. Blood and hepatic tissue samples were taken to examine several hematological and antioxidant parameters at 1 and 2 weeks post injection.

\section{Hematological parameter analysis}

Blood samples were collected within 35-40 s through the caudal vein of the fish in $0.5-\mathrm{mL}$ disposable heparinized syringes using a 30 -gauge needle. The syringes were kept at $4{ }^{\circ} \mathrm{C}$ until the blood parameters were completely studied. The total red blood cell (RBC) count, hemoglobin $(\mathrm{Hb})$ concentration, and hematocrit $(\mathrm{Ht})$ value were determined immediately. The blood samples were centrifuged to separate erythrocytes from serum at 3,000 $\mathrm{g}$ for $15 \mathrm{~min}$ at $4^{\circ} \mathrm{C}$. Total $\mathrm{RBC}$ counts were made according to Klontz (1979) using modified Yokoyama diluting fluid and a Spencer Bright-Line hemocytometer. The $\mathrm{Hb}$ concentration was determined using the Drabkin and Austin cyanmethemoglobin technique (Kit 525; Sigma). The Ht value was determined by the microhematocrit centrifugation technique. The serum samples were analyzed for inorganic phosphorus by the ultraviolet method (Kit 360; Sigma) and for calcium (Kit 588; Sigma), magnesium (Kit 595; Sigma), and chloride (Kit 461; Sigma) by the colorimetric method. Plasma osmolality was measured directly using $20 \mu \mathrm{L}$ of sample on a Micro-Osmometer (Model 3300; Advanced Instruments, Inc., Norwood, MA, USA).

\section{Antioxidant enzyme analysis}

Liver tissues were excised and homogenized with 5 volumes of ice-cold homogenization buffer (50 mM Tris, $\mathrm{pH} 7.5$, $1 \mathrm{mM}$ EDTA, $1 \mathrm{mM}$ DL-dithiothreitol, and $150 \mathrm{mM} \mathrm{NaCl}$ ) with several strokes using a Teflon pestle (099CK4424; GlasCol, Terre Haute, IN, USA). The homogenate was centrifuged at $12,000 \mathrm{~g}$ for $20 \mathrm{~min}$ under refrigeration and the obtained supernatants were stored at $-80^{\circ} \mathrm{C}$ for analysis. Glutathione peroxidase (GPx) activity was measured according to the method of Paglia and Valentine (1967) using cumene hydroperoxide as the substrate. To measure glutathione-S-transferase (GST) activity, the 1-chloro-2,4-dinitrobenzene (CDNB) method was used (Habig et al., 1974). Glutathione reductase (GR) activity was assessed by monitoring the oxidation of NADPH initiated by oxidized glutathione addition at $37^{\circ} \mathrm{C}$ (Cribb et al., 1989). Catalase (CAT) activity was measured as described by Johansson and Borg (1988).

\section{Statistics}

Statistical analyses were performed using the SPSS/PC+ statistical package (SPSS Inc., Chicago, IL, USA). Significant differences between groups were identified using one-way ANOVA and Duncan's test for multiple comparisons or Student's $t$-test for two groups (Duncan, 1955). The significance level was set at $P<0.05$. 


\section{Results}

\section{Hematological properties}

The RBC count, $\mathrm{Hb}$ concentration, and $\mathrm{Ht}$ value of olive flounders exposed to different levels of inorganic mercury are summarized in Table 2. The major hematological findings were a significant decrease in the RBC count and $\mathrm{Hb}$ concentration in olive flounders exposed to $>4 \mathrm{mg} \mathrm{Hg} / \mathrm{kg} \mathrm{BW}$ compared with the control group after 2 weeks $(P<0.05)$. The $\mathrm{Ht}$ value following inorganic mercury exposure for 2 weeks was also decreased in fish administered $8 \mathrm{mg} \mathrm{Hg} / \mathrm{kg}$ BW compared with the control group $(P<0.05)$.

\section{Inorganic components}

The blood serum inorganic components of olive flounder treated with inorganic mercury are shown in Table 3. No significant differences were observed in serum phosphorous or magnesium among the treatment groups. However, a clear decreasing trend was noted in serum calcium and chloride at 8 and $\geq 4 \mathrm{mg} \mathrm{Hg} / \mathrm{kg} \mathrm{BW}$, respectively, compared to the controls after 2 weeks $(\mathrm{P}<0.05)$. The control group maintained a normal blood osmolality (between 242 and $248 \mathrm{mOsm} / \mathrm{kg}$ ). However, at 1 and 2 weeks, the blood osmolality in the fish exposed to $>4 \mathrm{mg} \mathrm{Hg} / \mathrm{kg} \mathrm{BW}$ had significantly decreased compared to the controls $(P<0.05)$.

\section{Antioxidant enzymes}

The hepatic GPx, GST, GR, and CAT activity levels in fish exposed to inorganic mercury are presented in Fig. 1. GPx, GST, GR, and CAT activity in olive flounders treated with inorganic mercury at a concentration of $>2 \mathrm{mg} \mathrm{Hg} / \mathrm{kg}$ BW increased in a dose- and time-dependent manner. GPx and CAT activity in olive flounders exposed to inorganic mercury at concentrations $\geq 4 \mathrm{mg} \mathrm{Hg} / \mathrm{kg} \mathrm{BW}$ increased significantly compared to the controls after 2 weeks $(P<0.05)$. A significant in-

Table 2. Hematological parameters of olive flounder Paralichthys olivaceus exposed to the various inorganic mercury concentrations

\begin{tabular}{lccccc}
\hline \multirow{2}{*}{$\begin{array}{c}\text { Hematological } \\
\text { parameters }\end{array}$} & $\begin{array}{c}\text { Exposure } \\
\text { period (week) }\end{array}$ & \multicolumn{4}{c}{ Mercury dose (mg Hg/kg BW) } \\
\cline { 3 - 6 } & 1 & $\mathbf{0}$ & $\mathbf{2}$ & $\mathbf{4}$ & $\mathbf{8}$ \\
\hline RBC count $\left(\times 10^{4} / \mathrm{mm}^{3}\right)$ & 2 & $152.5 \pm 5.1^{\mathrm{a}}$ & $148.2 \pm 6.9^{\mathrm{a}}$ & $141.6 \pm 7.5^{\mathrm{ab}}$ & $134.8 \pm 4.2^{\mathrm{b}}$ \\
& 1 & $147.3 \pm 4.2^{\mathrm{a}}$ & $150.5 \pm 4.1^{\mathrm{a}}$ & $136.4 \pm 5.5^{\mathrm{b}}$ & $129.2 \pm 3.7^{\mathrm{b}}$ \\
$\mathrm{Hb}(\mathrm{g} / \mathrm{dL})$ & 2 & $9.4 \pm 0.9^{\mathrm{a}}$ & $9.8 \pm 1.1^{\mathrm{a}}$ & $7.9 \pm 0.6^{\mathrm{ab}}$ & $6.8 \pm 1.0^{\mathrm{bc}}$ \\
& 1 & $9.6 \pm 0.7^{\mathrm{a}}$ & $8.7 \pm 1.2^{\mathrm{ab}}$ & $7.1 \pm 0.5^{\mathrm{bc}}$ & $5.9 \pm 0.9^{\mathrm{c}}$ \\
$\mathrm{Ht}(\%)$ & 2 & $18.1 \pm 2.1^{\mathrm{a}}$ & $17.1 \pm 1.4^{\mathrm{a}}$ & $15.7 \pm 0.9^{\mathrm{ab}}$ & $14.1 \pm 1.1^{\mathrm{b}}$ \\
& 1 & $17.7 \pm 1.8^{\mathrm{a}}$ & $16.5 \pm 1.2^{\mathrm{a}}$ & $15.1 \pm 1.6^{\mathrm{ab}}$ & $13.7 \pm 0.8^{\mathrm{b}}$ \\
\hline
\end{tabular}

All data are expressed as mean \pm SE. Values with different superscripts in each parameter are significantly differences $(P<0.05)$ as determined by Duncan's multiple range test. $\mathrm{RBC}$, red blood cell count; $\mathrm{Hb}$, hemoglobin; $\mathrm{Ht}$, hematocrit.

Table 3. Inorganic components and osmolality of olive flounder Paralichthys olivaceus exposed to various inorganic mercury concentrations

\begin{tabular}{lccccc}
\hline \multirow{2}{*}{$\begin{array}{l}\text { Inorganic } \\
\text { components }\end{array}$} & $\begin{array}{c}\text { Exposure } \\
\text { period (week) }\end{array}$ & \multicolumn{4}{c}{ Mercury dose (mg Hg/kg BW) } \\
\cline { 3 - 6 } & 1 & $\mathbf{0}$ & $\mathbf{2}$ & $\mathbf{4}$ & $\mathbf{8}$ \\
\hline Phosphorous (mmol/L) & 2 & $2.52 \pm 0.15^{\mathrm{a}}$ & $2.43 \pm 0.09^{\mathrm{a}}$ & $2.58 \pm 0.09^{\mathrm{a}}$ & $2.47 \pm 0.12^{\mathrm{a}}$ \\
& 1 & $2.56 \pm 0.28^{\mathrm{a}}$ & $2.62 \pm 0.21^{\mathrm{a}}$ & $2.38 \pm 0.35^{\mathrm{a}}$ & $2.42 \pm 0.16^{\mathrm{a}}$ \\
Calcium (mmol/L) & 2 & $2.72 \pm 0.12^{\mathrm{a}}$ & $2.80 \pm 0.37^{\mathrm{a}}$ & $2.63 \pm 0.14^{\mathrm{a}}$ & $2.03 \pm 0.11^{\mathrm{b}}$ \\
& 1 & $2.69 \pm 0.25^{\mathrm{a}}$ & $2.76 \pm 0.25^{\mathrm{a}}$ & $2.32 \pm 0.21^{\mathrm{ab}}$ & $1.93 \pm 0.22^{\mathrm{b}}$ \\
Magnesium (mmol/L) & 2 & $1.45 \pm 0.15^{\mathrm{a}}$ & $1.56 \pm 0.30^{\mathrm{a}}$ & $1.67 \pm 0.22^{\mathrm{a}}$ & $1.51 \pm 0.16^{\mathrm{a}}$ \\
& 1 & $1.62 \pm 0.23^{\mathrm{a}}$ & $1.49 \pm 0.25^{\mathrm{a}}$ & $1.58 \pm 0.19^{\mathrm{a}}$ & $1.48 \pm 0.32^{\mathrm{a}}$ \\
Chloride (mmol/L) & 2 & $139.2 \pm 4.8^{\mathrm{a}}$ & $136.3 \pm 5.3^{\mathrm{a}}$ & $129.7 \pm 5.8^{\mathrm{ab}}$ & $123.5 \pm 5.4^{\mathrm{bc}}$ \\
& 1 & $141.4 \pm 7.2^{\mathrm{a}}$ & $134.8 \pm 4.6^{\mathrm{a}}$ & $122.2 \pm 4.2^{\mathrm{bc}}$ & $117.6 \pm 4.6^{\mathrm{c}}$ \\
Osmol (mOsm/kg) & 2 & $242.6 \pm 7.5^{\mathrm{a}}$ & $245.6 \pm 6.5^{\mathrm{a}}$ & $226.6 \pm 4.5^{\mathrm{b}}$ & $203.6 \pm 6.3^{\mathrm{c}}$ \\
& 2 & $248.4 \pm 8.3^{\mathrm{a}}$ & $234.4 \pm 7.2^{\mathrm{ab}}$ & $218.4 \pm 6.4^{\mathrm{bc}}$ & $199.4 \pm 5.6^{\mathrm{c}}$ \\
\hline
\end{tabular}

All data are expressed as mean \pm SE. Values with different superscripts in each organic components are significantly differences $(P<0.05)$ as determined by Duncan's multiple range test. 

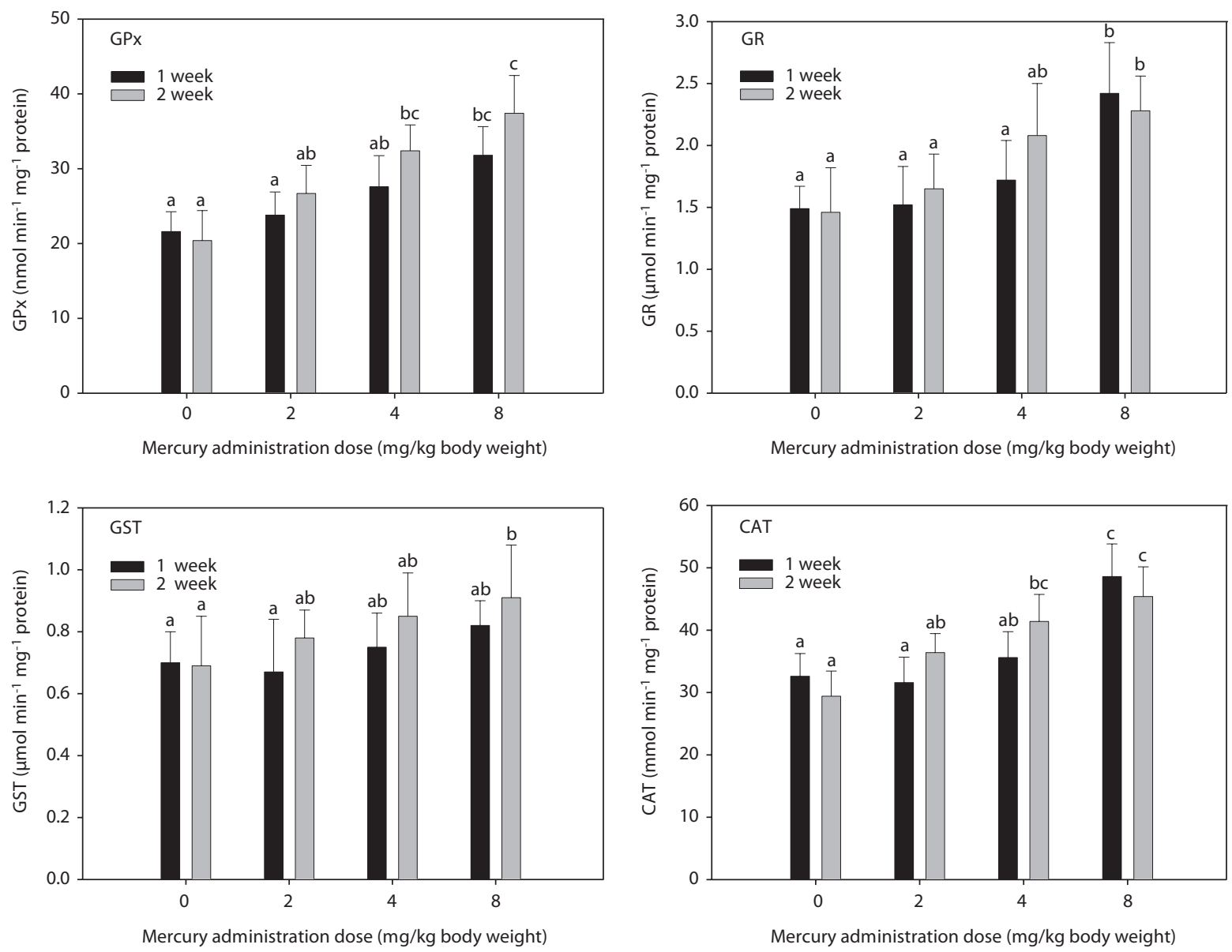

Fig. 1. Variations of glutathione peroxidase (GPx), glutathione S-transferase (GST), glutathione reductase (GR) and catalase (CAT) activities in the liver of olive flounder Paralichthys olivaceus exposed to the various inorganic mercury concentrations. All data are expressed as mean \pm SE. Different letters indicates significant differences $(P<0.05)$ between the groups.

crease in GST activity was observed at $8 \mathrm{mg} \mathrm{Hg} / \mathrm{kg} \mathrm{BW}$ after 2 weeks $(P<0.05)$. GR activity also increased at $8 \mathrm{mg} \mathrm{Hg} / \mathrm{kg}$ BW after 1 week $(P<0.05)$.

\section{Discussion}

The blood properties of fish are suitable biomarkers for evaluating the potential risk of chemicals (Roche and Bogé, 1996). Past investigators have identified changes in several hematological variables as indicators of heavy metal exposure (Cyriac et al., 1989). The predominant hematological findings in this study were a significant decrease in the RBC count and $\mathrm{Hb}$ concentration in olive flounders exposed to inorganic mercury at $>4 \mathrm{mg} \mathrm{Hg} / \mathrm{kg} \mathrm{BW}$. The Ht value in fish following inorganic mercury exposure to $8 \mathrm{mg} \mathrm{Hg} / \mathrm{kg} \mathrm{BW}$ for 2 weeks also decreased. Chronic exposure of fish to heavy metals causes serve reductions in the $\mathrm{RBC}$ count, $\mathrm{Ht}$, and $\mathrm{Hb}$ concentration (Tewari et al., 1987). Mercury has been shown to cause ane- mia in fish by inhibiting Hb synthesis and shortening the life span of circulating erythrocytes (Houston et al., 1993). These results are in accordance with those of mercury-exposed $\mathrm{Di}$ centrarchus labrax (Gwoździński et al., 1992), Oreochromis aureus (Allen, 1994), and Aphanius dispar (Hilmy et al., 1980), which exhibited higher mercury concentration-induced anemia. Our studies provide evidence that inorganic mercury affects hemolysis. The observed decline in RBC count, $\mathrm{Hb}$ concentration, and Ht presumably reflect hemolysis and/or irreparable damage to gill morphology and function (Gupta and Dua, 2002).

No significant differences in serum phosphorous or magnesium were detected among the treatment groups. However, a significant decrease in calcium and chloride was observed at 8 and $\geq 4 \mathrm{mg} \mathrm{Hg} / \mathrm{kg} \mathrm{BW}$, respectively, at 2 weeks. Previous laboratory studies have documented the inhibitory effects of various metals on gill function in fish (Evans, 1987; Watson and Benson, 1987). Indeed, the gills of freshwater teleosts function as the primary site for the active absorption of ions 
from the external medium and for the exchange of respiratory gases. Mercury can cause altered osmoregulation in both marine and freshwater fish. In this study, the blood osmolality of olive flounder exposed to $>4 \mathrm{mg} \mathrm{Hg} / \mathrm{kg} \mathrm{BW}$ was significantly decreased compared to the controls. This result can be explained by direct mercury-induced osmoregulation failure. Lock et al. (1981) suggested that mercury caused osmoregulatory effects primarily by increasing gill permeability to water. Stinson and Mallatt (1989) reported increased permeability of the gills in lamprey in response to mercury poisoning.

The main enzymes that detoxify reactive oxygen species in all organisms are GPx (EC 1.11.1.9), peroxidase (EC 1.11.1.7), and CAT (EC 1.11.1.6), all of which are abundant in fish tissue (Di Giulio et al., 1993). These enzymes, which are induced by reactive oxygen species, may be useful indicators of oxidative stress. The phase II system and endogenous cellular glutathione have received relatively little attention as environmental indicators (Stein et al., 1992). The induction of antioxidants is a sensitive early warning signal of incipient oxidative stress (Benson and Di Giulio, 1992). GST has been identified in all organisms in which it has been investigated (Diericx, 1984; Stenersen et al., 1987), and it seems likely that it is ubiquitous. GST activity is known to increase in rats exposed to polychlorinated biphenyls (Kamohara et al., 1984). The present findings corroborate the observations of Davies (1985) and Fair (1986) in fish exposed to chlorothalonil and benzo(a)pyrene, respectively.

Similarly, in a previous study, cadmium exposure in rainbow trout for 4 weeks caused an initial decrease followed by a net increase in hepatic GST (Förlin et al., 1986). In this study, hepatic GST activity in olive flounders toward CDNB after 2 weeks of exposure to $8 \mathrm{mg} \mathrm{Hg} / \mathrm{kg}$ BW was markedly elevated. These results demonstrate that GST activity was significantly altered by treatment with inorganic mercury. The status of other antioxidant systems is variably affected by polycyclic aromatic hydrocarbon (PAH) exposure (Niyogi et al., 2001; Veignie et al., 2004).

In this study, hepatic GR activity was significantly higher in fish exposed to $8 \mathrm{mg} \mathrm{Hg} / \mathrm{kg} \mathrm{BW}$ after 1 week compared to the controls. Similar results were reported by Stephensen et al. (2003), who observed increased hepatic GR activity in fish exposed to PAHs under laboratory conditions as well as increased GR activity in fish inhabiting a PAH-polluted harbor. GPx is the most important peroxidase for the detoxification of hydroperoxides. It catalyzes the glutathione-dependent reduction of hydroperoxides and hydrogen peroxide $\left(\mathrm{H}_{2} \mathrm{O}_{2}\right)$. GPx activity may be induced by environmental pollutants. Its activity increased together with GR in rainbow trout injected with tetrachlorobiphenyl (Otto and Moon, 1995) and carp exposed to copper, but not to paraquat (Matkovics et al., 1987). In this study, hepatic GPx and CAT activity in olive flounders exposed to inorganic mercury at $\geq 4 \mathrm{mg} \mathrm{Hg} / \mathrm{kg}$ BW was significantly elevated compared to the controls after 2 weeks. GPx has been postulated to protect erythrocytes from damage by
$\mathrm{H}_{2} \mathrm{O}_{2}$ and to be responsible for the reduction of lipid hydroperoxides. Therefore, it is hypothesized that this enzyme protects tissue against oxidative damage due to lipid peroxidation. The liver is a major site of detoxification and the first target of ingested oxidants; thus, it is considered to be an important tissue in the study of the protective role of GPx in lipid peroxidation. CAT occurs primarily in peroxisomes. Its activity increased together with other peroxisomal enzymes in fish liver upon exposure to bleached kraft mill effluents, suggesting the induction of peroxisome proliferation (Mather-Mihaich and Di Giulio, 1991). Some pollutants may inhibit CAT activity. High concentrations of copper were shown to inhibit CAT activity in liver, gill, and muscle; a similar effect was induced by 100 ppm of $\mathrm{ZnSO}_{4}$ in gill and muscle (Radi and Matkovics, 1988).

We conclude that exposure to a low concentration $(\geq 4$ $\mathrm{mg} \mathrm{Hg} / \mathrm{kg} \mathrm{BW}$ ) of inorganic mercury resulted in significant changes in several hematological and antioxidant parameters.

\section{References}

Allen P. 1994. Changes in the haematological profile of the cichlid Oreochromis aureus (Steindachner) during acute inorganic mercury intoxication. Comp Biochem Physiol C Pharmacol Toxicol Endocrinol 108, 117-121.

Benson WH and Di Giulio RT. 1992. Biomarkers in hazard assessments of contaminated sediment. In: Sediment Toxicity Assessment. Burton GA, ed. Lewis, Boca Raton, FL, US, pp. 241-256.

Bouquegneau JM. 1977. ATPase activity in mercury intoxicated eels. Experientia 33, 941-943.

Cribb AE, Leeder JS and Spielberg SP. 1989. Use of a microplate reader in an assay of glutathione reductase using 5,5'-dithiobis-2-nitrobenzoic acid. Anal Biochem 183, 195-196.

Cyriac PJ, Antony A and Nambisan PNK. 1989. Hemoglobin and hematocrit values in the fish Oreochromis mossambicus (Peters) after short term exposure to copper and mercury. Bull Environ Contam Toxicol 43, 315-320.

Dave G and Xiu RQ. 1991. Toxicity of mercury, copper, nickel, lead, and cobalt to embryos and larvae of zebrafish, Brachydanio rerio. Arch Environ Contam Toxicol 21, 126-134.

Davies PE. 1985. The toxicology and metabolism of chlorothalonil in fish. III. Metabolism, enzymatics and detoxication in Salmo spp. and Galaxias spp. Aquat Toxicol 7, 277-299.

Dierickx PJ. 1984. Glutathione S-transferase in aquatic macro-invertebrates and its interaction with different organic micropollutants. Sci Total Environ 40, 93-102.

Di Giulio RT, Habig C and Gallagher EP. 1993. Effects of black rock harbor sediments on indices of biotransformation, oxidative stress and DNA integrity in channel catfish. Aquat Toxicol 26, 1-22.

Duncan DB. 1955. Multiple range and multiple F tests. Biometrics 11, $1-42$.

Evans DH. 1987. The fish gill: site of action and model for toxic effects of environmental pollutants. Environ Health Perspect 71, 47-58.

Fair PH. 1986. Interaction of benzo(a)pyrene and cadmium on GSH-S- 
transferase and benzo(a)pyrene hydroxylase in the black sea bass Centropristis striata. Arch Environ Contam Toxicol 15, 257-263.

Fitzgerald WF and Clarkson TW. 1991. Mercury and monomethylmercury: present and future concerns. Environ Health Perspect 96, 159-166.

Förlin L, Haux C, Karlsson-Norrgren L, Runn P and Larsson Å. 1986. Biotransformation enzyme activities and histopathology in rainbow trout, Salmo gairdneri, treated with cadmium. Aquat Toxicol $8,51-64$.

Goyer R. 1991. Toxic effects of metals. In: Casarett and Doull's Toxicology: The Basic Science of Poisons. 4th ed. Amdur MO, Doull $\mathrm{J}$ and Klaassen CD, eds. Pergamon Press, New York, pp. 623-680.

Gupta N and Dua A. 2002. Mercury induced architectural alterations in the gill surface of a fresh water fish, Channa punctatus. J Environ Biol 23, 383-386.

Gwoździński K, Roche H and Pérès G. 1992. The comparison of the effects of heeavy metal ions on antioxidant enzyme activities in human and fish Dicentrarchus labrax erythrocytes. Comp Biochem Physiol 102, 57-60.

Habig WH, Pabst MJ and Jakoby WB. 1974. Glutathione S-transferase: the first enzymatic step in mercapturic acid formation. J Biol Chem 249, 7130-7139.

Hilmy AM, Shabana MB and Said MM. 1980. Haematological responses to mercury toxicity in the marine teleost, Aphanius dispar (Rüpp). Comp Biochem Physiol C 67, 147-158.

Houston A, Blahut S, Murad A and Amirkrtharaj P. 1993. Changes in erythron organization during prolonged cadmium exposure: an indicator of heavy metals stress? Can J Fish Aquat Sci 50, 217-222.

Johansson K, Aastrup M, Andersson A, Bringmark L and Iverfeldt A. 1991. Mercury in Swedish forest soils and waters: assessement of critical load. Water Air Soil Pollut 56, 267-281.

Johansson LH and Borg LAH. 1988. A spectrophotometric method for determination of catalase activity in small tissue samples. Anal Biochem 174, 331-336.

Kamohara K, Yagi N and Itokawa Y. 1984. Mechanism of lipid peroxidation in polychlorinated biphenyls (PCB) and dichlorophenyltrichloroethane (DDT)-poisoned rats. Environ Res 34, 18-23.

Klontz GW. 1979. Hematological techniques for fish. In: Fish Health Management: Concepts and Methods of Fish Disease Epidemiology. Vol. 2. Klontz GW, ed. University Of Idaho, Moscow, ID, US, pp. 100-130.

Lock RAC, Cruijsen PMJM and van Overbeeke AP. 1981. Effects of mercuric chloride and methylmercuric chloride on the osmoregulatory function of the gills in rainbow trout, Salmo gairdneri Richardson. Comp Biochem Physiol C Comp Pharmacol 68, 151-159.

Mather-Mihaich EM and Di Giulio RT. 1991. Oxidant, mixed-function oxidase and peroxisomal responses in channel catfish exposed to a bleached kraft mill effluent. Arch Environ Contam Toxicol 20, 391-397.

Matkovics B, Witas H, Gabrielak T and Szabó L. 1987. Paraquat as an agent affecting antioxidant enzymes of common carp erythrocytes. Comp Biochem Physiol C Comp Pharmacol 87, 217-219.

Nater EA and Grigal DF. 1992. Regional trends in mercury distribution across the Great Lakes States, north central U.S.A. Nature 358, 139-141.

Niyogi S, Biswas S, Sarker S and Datta AG. 2001. Antioxidant enzymes in brackishwater oyster, Saccostrea cucullata as potential biomarkers of polyaromatic hydrocarbon pollution in Hooghly Estuary (India): seasonality and its consequences. Sci Total Environ 281, 237-246.

Nriagu JO and Pacyna JM. 1988. Quantitative assessment of worldwide contamination of air, water and soils by trace metals. Nature 12, 134-139.

Otto DME and Moon TW. 1995. 3,3',4,4'-tetrachlorobiphenyl effects on antioxidant enzymes and glutathione status in different tissues of rainbow trout. Pharmacol Toxicol 77, 281-287.

Paglia DE and Valentine WN. 1967. Studies on quantitative and qualitative characterization of erythrocyte glutathione peroxidase. J Lab Clin Med 70, 158-169.

Radi AAR and Matkovics B. 1988. Effects of metal ions on the antioxidant enzyme activities, protein content and lipid peroxidation of carp tissues. Comp Biochem Physiol C Comp Pharmacol 90, 69-72.

Roche H and Bogé G. 1996. Fish blood parameters as a potential tool for identification of stress caused by environmental factors and chemical intoxication. Mar Environ Res 41, 27-43.

Stein JE, Collier TK, Reichert WL, Casillas E, Hom T and Varanasi U. 1992. Bioindicators of contaminant exposure and sublethal effects: studies with benthic fish in puget sound, Washington. Environ Toxicol Chem 11, 701-714.

Stenersen J, Kobro S, Bjerke M and Arend U. 1987. Glutathione transferases in aquatic and terrestrial animals from nine phyla. Comp Biochem Physiol C Comp Pharmacol 86, 73-82.

Stephensen E, Adolfsson-Erici M, Celander M, Hulander M, Parkkonen J, Hegelund T, Sturve J, Hasselberg L, Bengtsson M and Förlin L. 2003. Biomarker responses and chemical analyses in fish indicate leakage of polycyclic aromatic hydrocarbons and other compounds from car tire rubber. Environ Toxicol Chem 22, 2926-2931.

Stinson C and Mallatt J. 1989. Branchial ion fluxes and toxicant extraction efficiency in lamprey (Petromyzon marinus) exposed to methylmercury. Aquat Toxiccol 15, 237-251.

Swain EB, Engstrom DR, Brigham ME, Henning TA and Brezonik PL. 1992. Increasing rates of atmospheric mercury deposition in Midcontinental North America. Science 257, 784-787.

Tewari H, Gill TS and Pant J. 1987. Impact of chronic lead poisoning on the hematological and biochemical profiles of a fish, Barbus conchonius (Ham). Bull Environ Contam Toxicol 38, 748-752.

Veignie E, Rafin C, Woisel P and Cazier F. 2004. Preliminary evidence of the role of hydrogen peroxide in the degradation of benzo[a] pyrene by a non-white rot fungus Fusarium solani. Environ Pollut $129,1-4$.

Watson CF and Benson WH. 1987. Comparative activity of gill ATPase in three freshwater teleosts exposed to cadmium. Ecotoxicol Environ Saf 14, 252-259.

Weisbart M. 1973. The distribution and tissue retention of mercury-203 in the goldfish (Carassius auratus). Can J Zool 51, 143-150. 